\title{
Aikuisopiskelijoiden käsityksiä hyvistä ja huonoista opettajista
}

\author{
Christa Akerberg
}

\author{
Kun Christa Åkerberg haki seminaarityötänsä varten kir- \\ jallisuudesta tietoa hyvän aikuiskasvattajan ominaisuuk- \\ sista, hän löysi neljä eri ulottuvuutta: opettajan asenteen, \\ roolin, luonteenpiirteet ja opetuksen lähtökohdat. Por- \\ voon kauppaoppilaitoksen 22 aikuisopiskelijaa kirjoitti \\ hänen pyynnöstään omat kertomuksensa hyvästä \\ opettajuudesta. Mitä asioita he arvostivat?
}

$\mathrm{S}^{\mathrm{n}}$ uorittaessani MBA-tutkintoani Kanadassa Simon Fraserin yliopistossa vuosina 1999-2000 toimin opintojeni ohella laskentatoimen assistenttina. Ryhmien opettaminen oli osa toimenkuvaa, ja tällöin sain innostuksen jatkaa opettajana valmistuttuani. Vuoden 2001 keväästä alkaen olenkin työskennellyt eri aineiden ja mitä erilaisempien ryhmien opettajana. Opetustyö on aina yhtä haastavaa ja mielenkiintoista, mutta erityisesti minua on pohdituttanut se, mikä tekee yhdestä opettajasta hyvän ja toisesta huonon. Ihanteellinen aikuisopettaja on varmasti tuhattaituri, joka ryhmässä kuin ryhmässä erilaisten ihmisten ja oppijoiden ympäröimänä pystyy tarjoamaan kaikille kaikkea tavalla, joka miellyttää hyvinkin erilaisia ihmisiä samanaikaisesti. Mutta onko olemassa yhteisiä piirteitä, joiden avulla hyvä opettaja voidaan määrittää?

Opetustyöhöni liittyen päätin suorittaa aikuiskasvatustieteen cum laude approbatur -opinnot Helsingin avoimessa yliopistossa. Näihin opintoihin kuului myös seminaarityö, jossa tutkin lähemmin minua askartanutta kysymystä hyvästä opettajuudesta. Erityisesti keskityin aikuiskouluttajiin. Koska työskentelin lukuvuonna 2001-2002 Porvoon kauppaoppilaitoksessa, keräsin aineiston sen Yrityspalvelun aikuismerkonomioppisopimusopiskelijoiden keskuudessa.
T ähestyin hyvän opettajan kuvausta seminaa_ityössäni kahdesta vastakkaisesta näkökulmasta, toisin sanoen millainen on hyvä vs. millainen on huono opettaja. Huonon opettajan kuvausten avulla pyrin saamaan käsityksen myös kolikon kääntöpuolesta, sillä tieto huonon opettajan piirteistä voi osaltaan vahvistaa hyvän opettajan mallia tai kenties tuoda esiin piirteitä, jonka vastakohtia ei hyvän opettajan kuvauksista löydy. Koska hain kahta vastakkaista näkökulmaa, päätin käyttää apunani eläytymismenetelmää. Kehyskertomuksissa (kts. www.kvs.fi) tapahtunut variaatio koski hyvää / huonoa opettajaa. Yhteensä sain 22 vastausta. Näissä 10 kuvasi hyvää ja 8 huonoa opettajaa, kolmessa kuvattiin molempia. Yhden vastauksista jätin työn ulkopuolelle, sillä vastaajan vähäisen aikuisopiskelukokemuksen takia siinä ei otettu lainkaan kantaa aiheeseen.

Työhön kuuluvassa kirjallisuusosuudessa tarkastelin, mitä hyvän opettajuuden yleisiä teemoja kasvatustieteen kirjallisuudesta ${ }^{1}$ löytyy. Kirjallisuuden ja omien opetuskokemuksieni perusteella nimesin mielestäni vahvimmin esiintulleet neljä teemaa seuraavasti: opettajan asenne (kyky kohdata erilaisia oppijoita yksilöllisesti ja opetuksen muokkaaminen eri taitotasoille sopivaksi), opettajan rooli (oppimaan ohjaaja), opetuksen lähtö- 
kohdat (opetuksen työelämälähtöisyys) ja opettajan luonteenpiirteet (kyky luoda luokkaan molemminpuolisesti kunnioittava ja innostava ilmapiiri). Nämä neljä teemaa auttoivat minua jäsentämään keräämääni aineistoa.

Tarkastelin aikuisopiskelijoilta kerättyä aineistoa kahdella eri tavalla. Ensin katsoin, kuinka monessa kertomuksessa kukin teema tuli esiin saadakseni kuvan siitä, kuinka monelle vastaajalle teema oli tärkeä. Sitten laskin teemoihin liittyvien mainintojen kokonaismäärän tarkoituksenani selvittää, mikä teemoista on ollut kaikista tärkein vastaajille. Seuraavassa on kuvattu, mitä vastauksista tuli esille kunkin teeman osalta.

\section{Opettajan asenne}

$A_{\mathrm{k} i a}$ ikuisopiskelijoiden monimuotoisuuden takia on tärkeää, että jokaisen tarpeet tulevat otetuksi huomioon, muuten innostus opiskeluun herkästi loppuu. Opettajan asenteella oppilaita ja opetusta kohtaan tarkoitin kykyä kohdata erilaisia oppijoita ja tarjota heille yksilöllistä opetusta. Tämä teema nousi selkeästi esiin lähes puolessa kertomuksista. Yhteensä mainintoja oli selvästi enemmän huonojen kuin hyvien kuvauksissa, sillä piirre mainittiin huonojen opettajien kuvauksissa 15 kertaa, hyvien vain 7. Peilaten omiin kokemuksiini opiskelijana ja opettajana ajattelin, että voi hyvin olla, että asiaan ei kiinnitetä niin huomiota silloin, kun kaikki menee hyvin, mutta kun yksilöllisestä opetuksesta poiketaan, ei oppimisestakaan tule mitään.

Vastaajat pitivät tärkeänä nimenomaan sitä, ettei eteenpäin menty liian nopeasti ja että kysyä sai aina, kun jäi epäselvää. Tätä kuvaavat erityisen hyvin hyvää opettajaa kuvanneet kommentit "kärryiltä ei helposti tippunut ja jos tippui, niin tippunut haettiin kyytiin!!!" ja "opiskelijoilla oli erilaiset lähtökohdat ... jokaisella oli mahdollisuus päästä jyvälle" ja vastaavasti huonoa opettajaa kuvanneet kommentit "opettaja hosui, meni eteenpäin asiassa ennenkuin yksilöt olivat edes omaksuneet missä mennään” ja "opetus kulkee liikaa ns. hyvien oppilaiden osaamisen tahtiin, jolloin heikommat ja mahdollisesti hitaammin oppivat eivät pysy mukana".

Vastauksista suorastaan huokui opiskelijoiden hyvä ja turvallinen olo silloin, kun opettaja oli

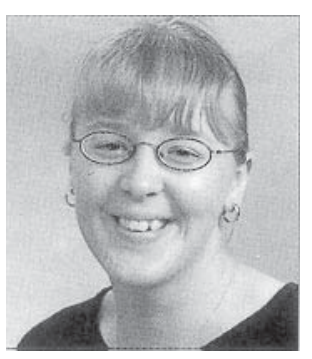

Christa Åkerberg

ottanut heidän erilaiset oppimistarpeensa huomioon. Opettajana saattaa joskus ajatella, että jos edetään hitaimpien tahtiin, nopeammat oppijat kyllästyvät. On kuitenkin huomattava, että kukaan vastaajista ei kuvannut huonona opettajana sellaista, joka oli edennyt liian hitaasti. Opettajalle on siis tärkeätä muistaa edetä riittävän rauhallisesti, vaikka materiaalia olisikin paljon. Oman opetusssuunnitelman orjallista seuraamista tärkeämpää on aina muistaa opiskelijoiden tarpeet.

Kaikista teemoista tämä nosti minulle esiin eniten ajatuksia. Kuinka vaikeata opettajana onkin muistaa, että opetettava aihe on opiskelijoille uutta ja vierasta, vaikka sen itse hallitseekin. Jos vielä unohtaa, että kysyminen ja opetuksen keskeyttäminen on monelle opiskelijalle suuri kynnys, tulee opettajana liian herkästi vain paahdettua eteenpäin siinä uskossa, että opiskelijat pysyvät perässä. Välillä opettajille tekeekin mielestäni hyvää opiskella itselle täysin vierasta ainetta, vaikkapa uutta kieltä. Ainakin itse huomaan vasta voidessani taas henkilökohtaisesti kokea aidon opetustilanteen pöydän toiselta puolelta, kuinka raadollista tunnilla on istua, jos putoaa kärryiltä.

\section{Opettajan rooli}

$\mathrm{M}$ yös opettajan rooli oppimaan ohjaajana noui joissain vastauksista esiin. Kuudessa hyvän ja kahdessa huonon opettajan kuvauksessa mainittiin, että opettajan aitous ja opiskelijoiden kanssa samalla tasolla oleminen oli tärkeää, sillä silloin oppilaat uskalsivat kysyä ja pääsivät eroon opiskeluun liittyvistä peloistaan. Tämä opettajan omaksuma rooli saattaa liittyä läheisesti edellä käsiteltyyn teemaan, asenteeseen, sillä opettajan asenne oppilaita ja opetusta kohtaan 
voi vaikuttaa siihen, minkälaista roolia hän yrittää pitää yllä luokassa. Mikäli opettaja kokee olevansa oppilaiden yläpuolella, hän saattaa uskoa tietävänsä itse parhaiten miten opettaa ja edetä. Tällöin etusijalle saattaa nousta edellisessä kappaleessa mainittu oman tuntisuunnitelman seuraaminen opiskelijoiden tarpeiden kustannuksella. On sanomattakin selvää, että tällainen ei kuulu hyvän opettajan piirteisiin.

\section{Opettajan luonteenpiirteet}

$\mathrm{I}_{\text {na }}^{\mathrm{n}}$ nnostava ilmapiiri korostui kertomuksissa, sillä opettajan luonteenpiirteet tuntuivat olevan vastaajille yksi tärkeimmistä hyvän opettajan piirteistä. Tästä antoivat osviittaa yhteensä yhdeksän hyvää opettajaa kuvanneen vastaajan tekemät peräti 21 mainintaa luonteenpiirteiden vaikutuksesta. Luonteenpiirteitä, jotka vastaajien mielestä auttoivat luomaan luokkaan innostavan oppimisilmapiirin olivat mm. eläväinen persoona, motivointi ja kannustus, kärsivällisyys, positiivisuus ja avoimuus. Aina lukiessani vastauksia tulin hyvälle tuulelle lukiessani seuraavan kommentin, joka mielestäni kuvaa oppimisen iloa hyvän opettajan tunneilla kaikista parhaiten: "... kyseinen opettaja oli joka kerralla aivan loistava... Hän ei ikinä hermostunut, oli aina hyvällä tuulella ja heti valmis auttamaan. Hän sai jokaisen yrittämään. Ja mikä tärkeintä; hän sai jokaisen onnistumaan!... Minulle jäi hyvä mieli ja toivon saavani vielä vastaavanlaista opetusta!!”

On mielenkiintoista pohtia, kuinka paljon opettaja pystyy vaikuttamaan omiin luonteenpiirteisiinsä, sillä onhan niin, että jotkut ihmiset ovat syntymästään saakka esimerkiksi eläväisempiä ja iloisempia kuin toiset. Koetaanko iloinen ihminen useammin parempana opettajana kuin joku toinen, yhtä osaava mutta vakavampi henkilö? Vai onko hyvässä opettajuudessa viime kädessä kuitenkin kyseessä monen tekijän summa, jolloin yksittäisellä piirteellä ei ole niin paljon merkitystä? Oikeaa vastausta minulla ei ole antaa, mutta ainakaan en ole tunneilla koskaan huomannut iloisuudesta ja positiivisuudesta olevan haittaa.

Huonojen opettajien kuvauksissa piirre ei puolestaan korostunut merkittävästi, sillä vain kolme vastaajista viittasi huonon opettajan epä- oikeudenmukaiseen, piitttaamattomaan ja epäystäväl-

liseen luonteeseen - kaikki piirteitä, jotka saavat ihmettelemään, miksi kuvatut ihmiset ovat ylipäänsä päättäneet ryhtyä opettajiksi.

Havaitsin kertomuksia lukiessani, että edelläkäsitellyt kolme teemaa, opettajan asenne, rooli ja luonteenpiirteet, ovat osittain päällekkäisiä. Koska opettaminen on aina monisäikeinen tapahtuma, on selvää, että sen onnistumiseen vaikuttavat useat tekijät. Osittain kertomuksia yhdistellen näin teemojen mahdollisen vuorovaikutuksen seuraavasti: hyvän opettajan positiivisuus ja avoimuus tuo luokkaan iloisen ja turvallisen ilmapiirin. Tällaisessa ilmapiirissä oppilaat uskaltavat kysyä ja kun kysymyksiin vastataan, he eivät putoa kärryiltä vaan kokevat oppivansa. Näin he tuntevat saavansa yksilöllistä kohtelua, jossa huomioidaan juuri heidän tarpeensa. Tällöin he myös kokevat opettajan olevan samalla tasolla kuin he itse. Toisaalta, jos opettaja ei vastaa oppilaiden kysymyksiin vaan sivuuttaa ne, opetukseen ollaan tyytymättömiä ja opettajaa pidetään huonona. Samalla opettajan nähdään yrittävän olla opiskelijoiden yläpuolella.

Nämä vastakkaiset näkökulmat tulivat esiin seuraavissa kommenteissa: "Hän korosti heti kurssin alussa, että ei ole tyhmiä kysymyksiä, on vain tyhmiä vastauksia, eli hän otti tavallaan itselleen syyn meidän tyhmyyteemme, ettemme me tuntisi itseämme niin huonoiksi" (oma suomennos ruotsinkielisestä kertomuksesta) ja toisaalta huonon opettajan kuvauksessa "opettajalla oli minusta rooli päällä että minä tiedän, minä osaan... hän sai koko päivästä hyvin hermostuneen, stressaavan". Hyvän opettajan kuvauksesta voidaan ymmärtää, että opettajan ottaessa syyn opiskelijoiden tyhmyyteen itselleen hän laskeutui oppilaiden tasolle ja loi luokkaan luottamuksellisen, turvallisen ilmapiirin. Huonon opettajan kuvauksesta voidaan puolestaan huomata, että opettajan hieman ylimieliseltä kuulostava auktoriteettirooli ei saanut osakseen kiitosta ainakaan tältä opiskelijalta.

\section{Opetuksen lähtökohdat}

$\mathrm{V}_{\mathrm{o}}$ iimeinen kirjallisuudesta nostamani teema oli opetuksen työelämälähtöisyys. Useimmilla aikuisopiskelijoilla on jo työelämää takanaan, ja 
opiskelemaan tullaan päämääränä parantaa omaa ammattitaitoa. Tämä teema nousi esille vain kolmessa hyvää ja huonoa opettajaa kuvanneessa tarinassa, yhteensä mainintoja oli kuusi. Asiasta kirjoittaneet vastaajat arvostivat käytännönläheistä opetusta ja sen käytettävyyttä työelämässä, kun taas teoreettista opetusta kaihdettiin. Seuraavat kommentit kertovat tästä opiskelijoiden sanoin: "Sain luennolta paljon uusia ideoita, tietoa ja varmuutta toimia työpaikallani", "opetettavan aiheen rinnastaminen arkipäivään kuului tuon opettajan kykyihin" ja toisaalta "mielestäni on turhaa käydä läpi asiakaspalvelun teoriaa, käytännön harjoittelusta saa enemmän irti” (oma suomennos ruotsinkielisestä kertomuksesta) ja "meinasi puutumus iskeä teoreettisiin aineisiin ja niiden opetustyyliin. Kauheat määrät ... ulkoa opiskeltavaa, aiheista joita ei tarvitse ja jotka opiskelee varmasti siinä vaiheessa kun niitä itse käytännönelämässä tarvitsisi”.

$\mathrm{T}$ yöelämälähtöisyyden tärkeyttä aikuisopiskelussa korostetaan kovasti, mutta itse jäin vielä miettimään, kuinka tärkeä asia tämä opiskelijoille itselleen todella on ja mitä sillä loppujen lopuksi tarkoitetaan. Aikuisten suorittaessa yksittäisiä omaan työtehtävään liittyviä kursseja odotukset työelämälähtöisyydestä ovat varmasti korkealla, mutta erilaisiin tutkintoihin saattaa sisältyä suurikin joukko aineita, joista opiskelijalla ei ole juurikaan hyötyä työelämässä. Kun opiskelija on kuitenkin päättänyt suorittaa tutkinnon, on hänelle selvää, että nämä kurssit tulee siitä huolimatta suorittaa. Tämä saattaa johtaa siihen, että opiskelija ei edes tule ajatelleeksi, että hänen saamansa opetuksen tulisi olla työelämälähtöistä; miten se voisi sitä olla, jos hän ei sitä itse työssään tarvitse? Työelämälähtöisyyden rinnalle nousi kuitenkin joissakin kertomuksissa yllämainittu käytännönläheisyys ja teoreettisen opetuksen kaihtaminen. Ovatko käytännönläheisyys ja työelämälähtöisyys ainakin osittain synonyymeja vai näkevätkö aikuiset nämä eri asioina?

Yhteensä seitsemässä, neljässä hyvää ja kolmessa huonoa opettajaa kuvanneessa vastauksessa nousi esiin myös aihe, jota en ennen aineiston käsittelyä ollut ajatellut: uuden oppiminen. Hyvänä esimerkkinä tästä oli seuraava kommentti: "Kurssin jälkeen oli hyvä olo ja oli taas oppinut jotain uutta, kiitos hyvän opettajan". Tässä työssä kumpikaan yllämainituista asioista (työelämälähtöisyys ja uuden oppiminen) ei tullut esille vahvasti merkityksellisenä. Sekä uuden oppiminen että opetuksen työelämälähtöisyys saattavat kuitenkin monelle olla ennakko-oletus kurssille tultaessa, jolloin näitä ei ehkä tule erikseen ajateltua tärkeinä tekijöinä, vaikka ne sitä olisivatkin. Olisikin mielenkiintoista katsoa, kuinka läheisesti nämä kaksi liittyvät toisiinsa. Teemaan "opetuksen lähtökohdat" voisi kenties yhdistää opetuksen toivotun lopputuloksen, uuden oppimisen, ja sen voisi nimetä uudelleen "opetuksen lähtökohdat ja oppimistulos". Näin se saattaisi kuvata paremmin sitä, miksi aikuiset ylipäänsä tulevat kurssille. Tämän huomioonottaminen lähtökohdissa johtaisi kenties varmemmin positiiviseen oppimistulokseen.

Miten sitten opettajana pystyy varmistamaan, että opiskelijat oppivat kurssilla jotain uutta? Konkreettinen, yhdessä opiskelijoiden kanssa luotu, opetussuunnitelmaan pohjautuva kurssisuunnitelma on yksi keino, joka on helppo toteuttaa ja helpottaa samalla opettajan omaa tuntisuunnittelua. Antamalla opiskelijoille ääni kurssisuunnittelussa mahdollistetaan myös yksi aikuiskoulutuksen rikkauksista, opettajan mahdollisuus oppia opiskelijoiltaan. Ainakin minä koen yhtenä työni helmistä mahdollisuuden keskustella eri näkemyksiä ja kokemuksia omaavien aikuisten kanssa meitä yhteisesti kiinnostavista liiketalouden ongelmista ja kehityssuunnista. Uskon myös opiskelijoiden arvostavan niitä opettajia, joiden he huomaavat olevan kiinnostuneita aidosta vuorovaikutuksellisuudesta, jossa molemmat osapuolet voivat oppia toisiltaan.

\section{Muita esiinnousseita piirteitä}

\eräämästäni aineistosta tuli esiin myös kolLme piirrettä, joita en ollut nimennyt ennen aineiston käsittelyä. Näistä ensimmäinen oli opettajan äänenkäyttö, johon läheisesti liittyi myös muuten selkeä opetustyyli. Äänenkäyttöä korostivat kolme hyvää ja viisi huonoa opettajaa kuvannutta vastaajaa, jotka kukin mainitsivat asiasta kerran. "Hän puhui selkeästi suhteellisen kovalla äänellä ja riittävän hitaasti”(oma suomennos ruotsinkielisestä kertomuksesta), "opettaja 
oli vahvaääninen" ja "hän puhui selkeällä, hyvällä äänellä" ja toisaalta taas "se että hän oli välillä selkä luokkaan päin ja mumisi asioita ei paljon antanut", "harmittaa opettajat jotka mumisevat luokan edessä ja ei tahdo kuulla mitä opettaja puhuu" ja "ääni on tasapaksua pötköä niin että melkein nukahtaa!" kertovat kaikki selkeän äänen tärkeydestä.

Opettajien koulutuksessa lienee syytä kiinnittää huomiota tähän, sillä jo pienillä parannuksilla voidaan saada ihmeitä aikaan opiskelijoiden oppimistuloksissa ja motivaation ylläpidossa. Lisäksi äänenkäyttö on asia, jota nimenomaan opettajankoulutuksessa voidaan harjoitella, kun taas opettajan asenteen tai luonteenpiirteiden muuttaminen voi olla huomattavasti vaikeampaa. Aihetta voidaan myös pitää omana teemanaan juuri siitä syystä, että siihen voidaan vaikuttaa muista tekijöistä riippumattomasti.

Toinen huomioni kiinnittänyt seikka oli viidessä tarinassa (neljässä hyvässä ja yhdessä huonossa) korostuneet opettajasta riippumattomat tekijät, joista oli yhdessä tarinassa kaksi mainintaa, eli yhteensä kuusi mainintaa. Erityisesti nämä vastaajat kertoivat Porvoon kauppaoppilaitoksesta, jossa oppisopimusopiskelijat opiskelevat päivän viikossa ja ovat neljä päivää töissä. Opiskelijat totesivat, että tuntien vähäinen määrä johtaa välillä vaikeuksiin tuntien suunnittelussa ja hyvinkin kovaan opiskelutahtiin. Välillä saman kurssin tuntien välillä voi olla pitkäkin väli aikataulullisista syistä, ja tämä hajanaisuus heikensi opiskelijoiden mielestä oppimisen laatua.

Ongelmat ovat luultavasti samansuuntaisia muissa oppilaitoksissa, jotka järjestävät opetusta samalla periaatteella. Tämä on huomionarvoinen asia opetuksen suunnittelijoille, joiden tehtävänä on tehdä niin oppimisesta kuin opettamisestakin mahdollisimman helppoa opiskelijoille ja opettajille. Koska hyvä opettaja saattaa hallita nämä hänestä suoranaisesti riippumattomat tekijät huonoa paremmin (esimerkiksi kyky opettaa asioita tehokkaasti, tiiviisti ja selkeästi lyhyessäkin ajassa hosumisen sijaan), pidin tätä vielä omana teemanaan opettajasta riippumattomien tekijöiden hallinta. Tätä teemaa käsitelleitä vastauksia oli suhteellisen vähän, ja tämä saattaa olla seurausta siitä, että tällaiset opettajasta riippumattomat tekijät ovat enemmän suunnittelijoiden ja opettaji- en kuin oppilaiden murhe. Niinpä tätä teemaa olisi mielenkiintoista tarkastella lähemmin juuri suunnittelijoiden ja opettajien näkökulmasta. Nostin sen tässä työssä itsenäiseksi kategoriaksi lähinnä siksi, että se ei painuisi unohduksiin.

Seitsemässä kertomuksessa mainittiin myös opettajan ammattitaito, ts. asiahallinta. Jokainen näistä seitsemästä kuvasi hyvää opettajaa, eli kukaan ei maininnut opettajan olleen huono ammattitaidon puutteen takia. Hyviä opettajia kuvanneilla tämä piirre ei ollut kertomuksen keskipisteenä, vaan se tuntui olevan suhteellisen pienessä roolissa lähinnä muita positiivisia piirteitä tukemassa. Tämä on mielenkiintoista, sillä olen ajatellut, että etenkin aikuisopiskelijat olisivat kriittisiä nimenomaan ammattitaidon suhteen, koska heillä itsellään on usein kokemusta opiskeltavasta aineesta. Kenties onkin niin onnellisesti, että koulutusinstituutiot, joissa vastaajat ovat aikuisina opiskelleet, ovat keskimäärin onnistuneet hyvin opettajien palkkauksessa ja että suurin osa aikuisia opettavista ihmisistä osaa asiansa ja tietää, mistä puhuu.

\section{Opetus m e n e t e l m ät}

【opuksi oli mielenkiintoista huomata, että käy —etyillä opetusmenetelmillä (ryhmä- / yksilötyöt tms.) ei tuntunut olleen vaikutusta siihen, millaisena opettajia oli koettu. Konstruktiivisen oppimiskäsityksen mukaan aikuisopetuksessa tulisi käyttää lähtökohtana oppilaiden omia kokemuksia ja heitä aktivoivia menetelmiä. Kertomuksissa vastaajien mielipiteet opetusmenetelmistä menivät ristiin siten, että yksi piti suorasta muistiinpanojen kopioimisesta kalvolta, toinen ryhmätöistä ja kolmas yksilötöistä. Tärkeintä oli kaikille vain, ettei edetty liian nopeasti. Voisiko olla niin, että kun oppimisilmapiiri luokassa on hyvä, ei käytetyllä opetusmetodilla ole niin suurta merkitystä? Koska opetusmetodit eivät tulleet kovinkaan merkittävästi esille, en käsitellyt niitä erillisenä teemana.

\section{Yhteenvetoa}

T yön tuloksena nimesin yhteensä seitsemän hyvään opettajuuteen liittyvää teemaa. Nämä olivat 1. opettajan asenne, 2. opettajan rooli, 3 . 
opettajan luonteenpiirteet (käyttäytymispiirteet), 4. opetuksen lähtökohdat ja oppimistulos, 5 . äänenkäyttö, 6. opettajasta riippumattomien tekijöiden hallinta ja 7. opettajan ammattitaito.

Merkityksellisimmäksi aineistossa nousi opettajan kyky luoda positiivinen oppimisilmapiiri. Ainoastaan turvallisessa ja myönteisessä oppimisilmapiirissä oppilaat uskalsivat kysyä silloin, kun heille jäi asioita epäselväksi. Huonon opettajan tunneilla kuvattiin ilmapiiri negatiiviseksi, lähes epätoivoiseksi. Siinä opiskelijat lopulta luovuttivat yrityksen oppia todettuaan, ettei opettaja halunnut kuunnella heitä. On selvää, että moni aikuisista ei ole valmis käyttämään vapaaaikaansa sellaisilla tunneilla istumiseen, joilla he kokevat olonsa epämukavaksi. Ihmisen luonteeseen on melko vaikeata vaikuttaa, joten voimme vain toivoa, että aikuisten opettajiksi hakeutuu ainoastaan ihmisiä, jotka ovat luonteeltaan positiivisia, iloisia ja kannustavia. Toisaalta jokainen opettaja voi reflektoida omaa käytöstään luokassa ja miettiä, miten kenties voisi parantaa luokan ilmapiiriä omaa käytöstään muuttamalla. Pienetkin muutokset saattavat olla yllättävän merkityksellisiä.

Toiseksi merkityksellisin teema oli opettajan taito kohdata erilaisia oppijoita ja tarjota heille yksilöllistä opetusta. On tärkeätä, että omasta oppimiskyvystään epävarmoille aikuisille osataan tarjota tarpeeksi yksilöllistä tukea ja mahdollisuuksia edetä asioissa omaan tahtiin, että heidän motivaationsa opiskella säilyy. Tähän opetuksen piirteeseen on jo onneksi helpompi vaikuttaa kuin opettajan luonteeseen, sillä jokainen opettaja voi itse miettiä, tarjoaako opetusta tavalla, joka mahdollistaa kaikkien kärryilläpysymisen. Onneksi osa aikuisista itse kommentoi opettajalle, mikäli tämä etenee liian nopeasti. Tällöin opettajan on tärkeää kuunnella, mitä opiskelijoilla on sanottavana ja olla tarpeeksi nöyrä ja valmis muuttamaan omaa opetussuunnitelmaansa ja -tapaansa. Tätä voi harjoitella niin omassa työssään kuin opettajankoulutuksessakin.

Opetuksen lähtökohtiin ja oppimistulokseen liittyi aikuiskoulutuksen keskeinen piirre, työelämälähtöisyys ja toisaalta halu oppia uusia taitoja nimenomaan työtä varten. Seminaarityöni vastaajien mukaan hyvä opettaja otti huomioon opiskelijoiden pitkän taustan työelämässä ja teki asioista käytännönläheisiä rinnastamalla asioita arkirutiineihin. Tämän lähestymistavan tuloksena opiskelijat mainitsivat iloisena, kuinka he hyötyivät kurssista suoraan ja käyttivät opittuja taitoja jokapäiväisessä työssään. Opettajan kyvyttömyys opettaa asioita käytännönläheisesti johti siihen, että kyseisen opettajan tunneilla ei koettu opittavan mitään hyödyllistä. Tämän teeman alle sisältyy asioita, jotka ovat osittain opettajasta riippumattomia. Saattaa olla, että opetussuunnitelmaan sisältyy aineita, jotka ovat teoreettisempia ja vähemmän käytännönläheisiä kuin toiset. Hyvän opettajan taito erityisesti tällaisten aineiden opettamisessa piileekin kyvyssä muokata opetusta mahdollisimman käytännölliseksi.

Äänenkäyttö ja selkeä opetustyyli nousivat myös vastauksissa esille. Hyvät opettajat puhuivat selkeällä, kuuluvalla äänellä ja tarpeeksi hitaasti, ja heidän opetuksensa eteni loogisesti asiasta toiseen. Mielestäni etenkin tähän seikkaan voidaan opettajia koulutettaessa ja töihin valitessa kiinnittää huomiota ja ongelmat voidaan helposti havaita esimerkiksi näytetunnin aikana.

Kertomuksissa esiin nousivat erityisesti ajan rajallisuus ja tarve käsitellä suuria määriä uusia asioita pienen tuntimäärän ja hajanaisten tuntien puitteissa. Opettajasta riippumattomien tekijöiden hallintaan liittyi kyky tehdä opetuksesta tehokasta ja toimivaa ulkoisten tekijöiden aiheuttamista esteistä huolimatta. Tällaisia ovat vaikkapa puutteelliset opetusvälineet tai meluisat tai ahtaat opetustilat. Mielenkiintoista olisikin tutkia tätä teemaa lähemmin, sillä parantamalla opetusoloja helpotetaan opettajien työtä ja mahdollistetaan entistä parempi opetus ja sitä kautta opiskelijoiden suurempi tyytyväisyys.

Itselleni kertomusten lukeminen ja niiden pohtiminen antoi välineen tarkastella omaa opetustani järjestelmällisemmin. Opiskelijoiden kertomukset olivat monipuolisia ja rikkaita ja auttavat minua kehittymään työssäni tarjoamalla vertailupohjaa oman opettamisen reflektoimiseen. Toivon työstäni olevan vastaavaa hyötyä muillekin opettajille.

$\mathrm{V}$

IITE. Luokittelun pohjana oli kirjallisuuden anta maa suuntaa hyvästä opettajuudesta. Kirjallisuus ja kehyskertomukset löytyvät nettisivulta www.kvs.fi $>$ Aikuiskasvatusjulkaisut $>$ Aikuiskasvatus > Tärppejä nettilukijalle. 